AP: Ontine Journat in Public Archaeology Special Volume 3 - 2018 p. 55-78

\title{
Public Engagement through Burial Landscapes: Cupids and Ferryland, Newfoundland
}

Robyn LACY

Memorial University of Newfoundland

Received: 19/08/2017 - Accepted: 28/06/2018

\begin{abstract}
British occupation of Newfoundland dates to the early 1600 s with the founding of settlements such as Cupids and Ferryland. While records of deaths exist at both colonies, their seventeenth-century burial grounds have not been located. Historic burial grounds in Newfoundland come with certain characteristic features: surviving gravestones in a rocky landscape, views of the ocean, and often a large cross on top of a hill. Though not visible at the sites in question, these 'lost' burial landscapes can be employed as an engagement tool by archaeologists. By exploring a 'lost' burial landscape with visitors, a dialogue is opened to speculate where the settlers were buried and why. While indirect, discussing these themes with visitors provokes thought on historic vs. modern burial practices and acknowledges the seventeenth-century dead within the context of the modern landscape. This article aims to explore the use of burial landscapes to engage visitors in a conversation about early colonial history, but also about mortality in both historic and modern contexts.
\end{abstract}

\section{Keywords}

burial ground, engagement, intangible, landscape, Newfoundland 


\section{Introduction}

The article aims to explore ways in which archaeologists and tour guides at the historic sites of Cupids and Ferryland, Newfoundland and Labrador, can use the 'lost' seventeenth-century burial landscape to encourage dialogue about death, both historic and modern. Through engagement with archaeological research on death, dying, and burial, interested members of the public can be encouraged to ask frank questions about death in history, thus opening discussions on, and comparisons with, contemporary burial practices. I reflect on how archaeology can foster engagements with the public about mortality by creating an environment where such engagement is open, frequent and encouraged (see also Sayer 2010). My case studies explore this topic by considering how archaeology can alert local communities and archaeologists to the presence of early colonial graveyards, even when memorials might be displaced or long gone.

The excavation at Ferryland was conducted as a part of my Masters research at the Memorial University of Newfoundland, searching for evidence of burial shafts that could indicate the early seventeenth-century burial ground at the 1621 settlement. During the ten weeks of excavation, I made many observations regarding the public's reactions and questions regarding my research, and the concept of burials being potentially anywhere within the settlement, which fueled this research.

\section{Death and burial in colonial Newfoundland}

During attempts in the 1600s by the British to establish yearround settlements on the coast of the island of Newfoundland, immigrants were faced with an unfamiliar environment. There exist records of many settlers' deaths during the first few years of settlement (Cell 1982; Guy 1611). While death is inevitable, early British colonies often had to cope with the dead before they were able to implement or adapt an existing system (including ritual practices and burial grounds) of disposal and commemoration. Their bodies would become some of the first European deposits deliberately placed in the environs of these settlements. Often early burial 
grounds on the east coast of North America were not associated with contemporaneous churches, and while churches may have been constructed at some sites later on, in regards to the case study sites, as well as many sites in eastern Newfoundland, later cemeteries did not append these early burial grounds (Lacy 2017). Unidentified or unlocated seventeenth-century burial grounds are thus the result of the original burial space not being reused as a burial ground or cemetery at a later date, the monuments being removed or destroyed, and their locations lost, or a combination of these two processes. The burial landscapes at the case study sites, London and Bristol Company's Cupids Plantation (established in 1610) and George Calvert's Colony of Avalon at Ferryland (1621) (Cell 1969; 1982), are known to history through documents recording the deaths of settlers, but these have not endured as known features within the modern landscape. Therefore, through uncovered archaeological features of the historic settlements, archaeologists and visitors can today actively engage with hitherto hidden dimensions of the seventeenth-century landscape. When presented with the idea of an unidentified colonial burial ground at these archaeological sites, a distinctive engagement with the space transpires: visitors are inspired to question where burials might be located, and why they might be in different locations to cemeteries established at later dates.

Many colonial settlements in eastern North America such as Jamestown (1607), Cupids (1610), Plymouth (1620), and Ferryland (1621), experienced high mortality rates in the first few years, prior to their earliest surviving gravestones. Early graves may have been left unmarked, or indicated with a biodegradable material (i.e. a wooden cross), which will have long since rotted, leaving them virtually invisible on the modern landscape. Markers like these are only sometimes visible in the archaeological record, for example through traces of a post-hole. As a result, these earliest burial monuments/grounds can be overlooked when compared with highly visible, and enduring, stone monuments of the later seventeenth and eighteenth centuries (Bartram 1978; Baugher and Veit 2014; Mytum 2004, 18). We can call these 'lost' burial landscapes: early burial grounds within the landscape of a historic site or space, unbeknownst to visitors passing through, and often unrecorded in existing archaeological and historical records. Through active 
and open discussion on these early burial grounds, aspects of an historic site that engage with mortality and burial can be made more accessible to visitors. Such engagement can evoke a different understanding of the landscape in which these settlements are presently situated.

Before proceeding, it is essential to reiterate that the burial sites discussed in this paper are associated with colonial settlements in Newfoundland. No Indigenous burials were explored or disturbed during this project, although it is important to acknowledge that these colonial settlements were built on the traditional territory of the Beothuk people. With this research, I suggest an aspect of the burial landscape that could be employed to open discussions on mortality at historic settlement sites; however, the study of an Indigenous burial ground requires an understanding of different ethical dimensions to archaeological practices. In current practice, Indigenous burial grounds should not be investigated without the express consent and support of the Indigenous community, as the impacts of colonial archaeological research are still palpable in North America today (e.g. McGee 2008; Phillips and Allen 2011; Giles and Williams 2016).

\section{Public engagement with the burial landscape}

Archaeologists inherently deal with death. Mortuary archaeology can be used to explore not only the contents of graves, but the monuments, memorials, structures, and other aspects of the burial landscape beyond the confines of the burial ground itself, and within those, social relationships with death. These themes are explored in terms of the past, but extend to our present understanding of mortality, closely examined by archaeologists and the public at burial sites (Meyers and Williams 2014: 152). While people are often fascinated by burial practices throughout history, today we in the Global West deal with our own mortality in an often-indirect way. In a period where death and dying in the Western world are often kept away behind the closed doors of funeral homes and hospitals, archaeology can offer a less visceral way to interact with mortality through the long-dead (Giles and Williams 2016; Meyers and Williams 2014: 155; Sayer 2010). 
The term 'burial landscape' implies not only the physical burials themselves, but also the space's interconnectedness with the community, and with a wider expanse of burial practices within a society. Burial landscapes can be explored through community participation and engagement, without the public being exposed to potentially controversial subjects such as public viewing of human remains, especially important in places where community members could feasibly be the living descendants of the deceased buried at the archaeological sites in question. Through researching and experiencing landscapes associated with and populated by the dead, the social, legal, and political complications that occur with the uncovering and exhumation of human remains can, for the most part, be avoided. In North America, colonial burial grounds have been the subject of much interdisciplinary research, from archaeologists (Baugher and Veit 2014) and art historians (Blachowicz 2006; Slater 1987) to genealogical research through websites such as Ancestry (2018) or historical society groups on Facebook such as the Greenspond Historical Society (2018). As a result, these historic cemeteries have both physical and digital presences in contemporary society.

A landscape embodies the views, practices, and activities of those who inhabited it (Jackson 1984; Anschuetz and Scheick 1998). While burial landscapes and memory have been a recent subject of study (Cannon 2002; Rugg 2013; Baugher and Veit 2014), these spaces have primarily been those clearly delineated and remaining in use and thus commonly known. 'Lost' burial landscapes may not be immediately recognizable to archaeologists or public, but that does not mean that the landscape is devoid of potential knowledge. The knowledge that there is a burial ground somewhere close by can influence the way in which local people interpret the use of their quotidian space, and it is this potential that can be utilized by public archaeologists. While any element of the historic landscape that cannot be directly observed may not seem as sensational to interested audiences as human remains, this aspect of colonial mortuary archaeology can be seen as an attempt to encourage researchers and visitors focus on the many other elements that comprise a mortuary environment (Mytum 2004; Williams and Atkin 2015: 15). Further, by contemplating the burial spaces of the past, individuals can consider burial spaces of the present (Figure 1). 


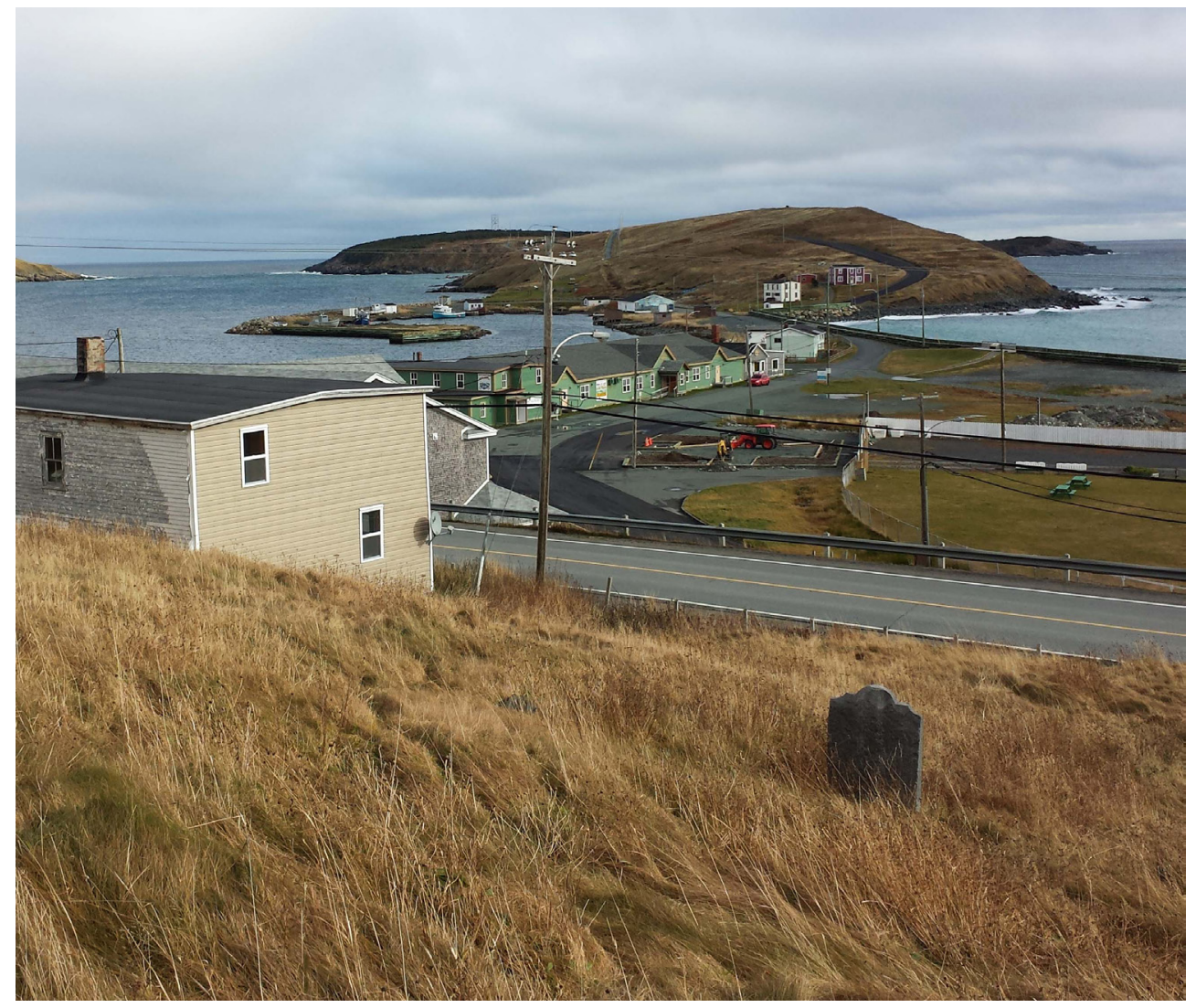

Figure 1: View from the known historic Old Non-Denominational Burial Ground at Ferryland towards the site of the 1621 settlement and its lost burial landscape (photo by author, 2015).

\section{Cupids and Ferryland}

Cupids and Ferryland are among some of the oldest colonial British settlements in North America. Initially established as economic ventures by the Newfoundland Company (another name for the London and Bristol Company) (Gilbert 2003: 117) and Sir George Calvert, the First Lord Baltimore, respectively, these settlements set out to carve a profitable British colonial foothold on the island of Newfoundland (Figure 2). Similar to other early colonial settlements, Cupids and Ferryland were heavily fortified, primarily against attacks from other Europeans. Cupids boasted 


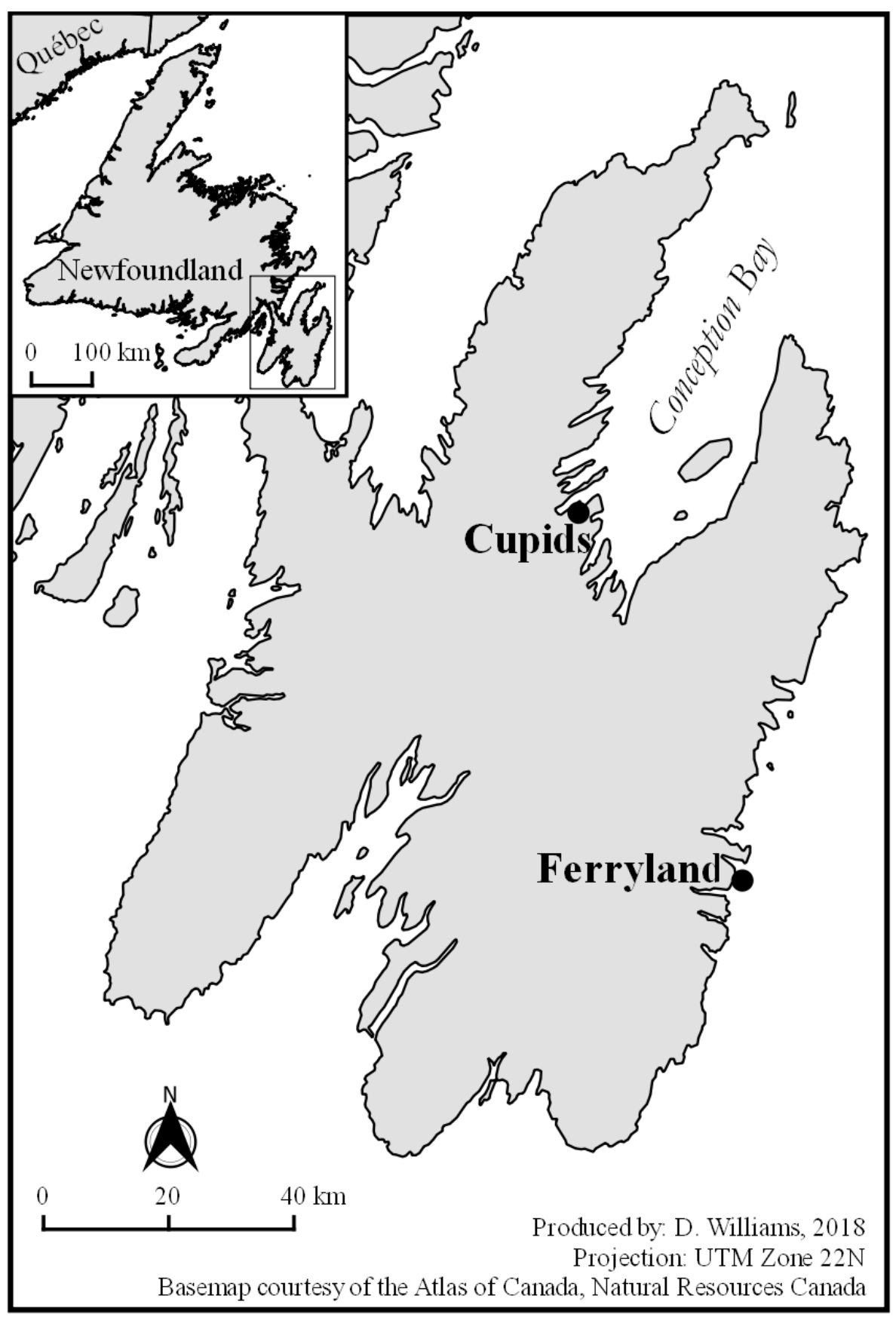

Figure 2: Map showing Newfoundland's Avalon Peninsula, with Ferryland and Cupids indicated with stars (map by Duncan Williams 2018, printed with permission). 
a large stone fortification facing the harbour with three cannons overlooking the water (Gilbert 2003: 118), while Ferryland was surrounded by a deep ditch, earthwork embankment, high wooden palisade, and bastion earthwork, with a cannon trained on the entrance to the protected harbour (Miller 2013: 252; Tuck and Gaulton 2003: 190). Both settlements are known through surviving contemporary letters which outline some of the structures that were built, what was grown, and even the climate, but there are no mentions of a burial ground. Talk of death was certainly not taboo in the seventeenth century (Stannard 1977), but perhaps the burials were not mentioned in records to disguise the harsh reality of colonial settlement in North America for benefactors back in England. At least in the case of Ferryland, documentary evidence indicates that Captain Edward Wynne purposefully omitted details about life in Newfoundland in letters to the colony's benefactor, when he called Ferryland 'as pleasant and as profitable a Harbour as any in the Land' (Cell 1982: 254). Like much early literature on Newfoundland, he promoted the island's 'favourable climate' (Gaulton and Miller 2009: 114). Early records from settlements such as Boston contain frank discussions of death and burial, yet details of the burial grounds themselves are not often given (Morton 1669; Sewall 1878).

Surviving records from Cupids detail the individuals who died at the plantation during the early years of the settlement. Their names and causes of death were recorded, and research on similar settlements suggests that they would have been buried in or near the plantation (Lacy 2017). In 2008, several graves were identified to the east of the main settlement, marked with rough stone and two eighteenth-century headstones (Gilbert 2008) (Figure 3). Archaeologists at Cupids have suggested that the narrow width of three of the grave shafts could indicate that they were dug during the seventeenth century. However, a seventeenth-century date for this site has yet to be confirmed (Cupids400 ND; Gilbert 2013: 84).

Few written records survive from Ferryland during this early period of settlement. Letters from Captain Edward Wynne, the colony's first governor, provide archaeologists a glimpse into the first few years but (as noted above) while the letters detail construction efforts and requests for supplies, they are also 


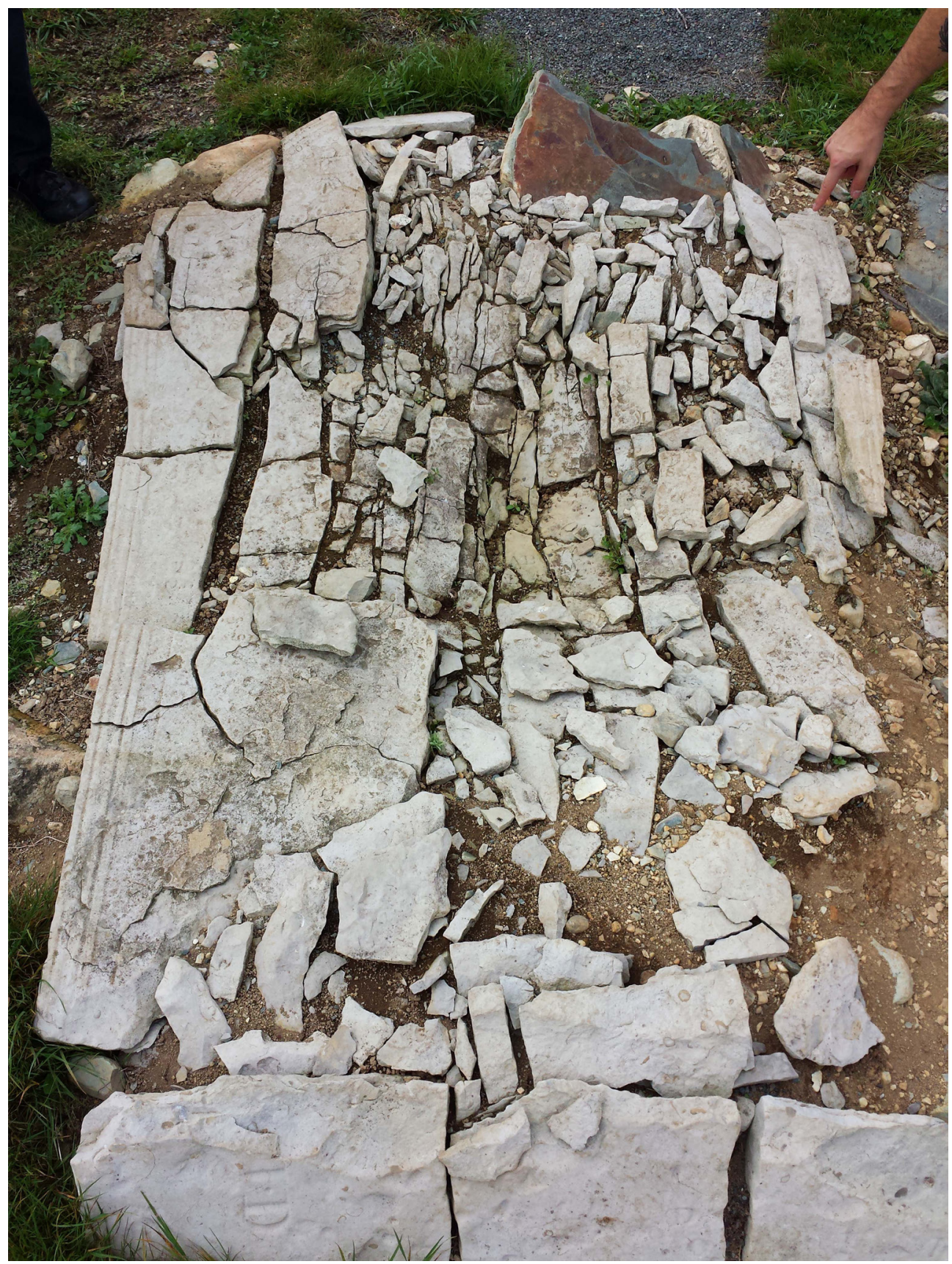

Figure 3: Eighteenth-century headstone at Cupids made from imported stone. Some letters and a border decoration are visible (photo by author, 2015). 
propaganda to maintain the support of George Calvert, the colony's benefactor and founder (Cell 1982). When Calvert moved himself and his family over to Ferryland in 1628 , he found the environment much less desirable than was previously described, and a letter from the particularly tough winter of 1628/9 describes a sickness that ravaged the colony. Not long before he left his Ferryland colony for good in 1629, Calvert wrote to King Charles stating 'my howse hath been an hospital all this winter, of $\underline{100}$. persons $\underline{50}$. sick at a tyme, myself being one and nyne or ten of them dyed.' (Cell 1982). However, Calvert did not give up on North American colonization, and although he died in London in 1632, his sons went on to found the settlements of St. Mary's City and Baltimore, Maryland. Several individuals died at Ferryland in 1628 - sadly, no records have survived that might indicate their names, cause of death, or burial locations.

Ongoing research at both historic sites seeks to identify these early seventeenth-century burial grounds, which are likely the first British burials in colonial Canada. I have conducted research into the burial landscapes of early seventeenth-century British North America in an attempt to identify patterns in the spatial relationship between burial locations and settlement structures of early colonies, and, during 2016 and 2017, applied the resulting dataset to the search for the first British burial ground at Ferryland (Lacy 2017).

The statistical analysis of similar sites suggested that the most likely location for burials at Ferryland might be an elevated landform, such as a hillside or hilltop, located in the centre of a settlement, or an eastern location from the centre of a settlement (Lacy 2017). In 2016, locations to the east and south from the centre of the settlement were investigated for human burials using selective excavation units informed by geophysical survey. In 2017, the excavation focused on a central location within the fortified settlement, due to the likelihood of the location based on the statistical evidence presented in the model. This was close to where three seventeenth-century decontextualized gravestone fragments were recovered during excavations in previous years, further suggesting that a burial ground may have been located nearby (Carter et al. 1998; Gaulton 2006, 88; Lacy et al. 2018). After two seasons of excavation, the exact location of the burial 
ground remains unknown, suggesting that Ferryland is anomalous for early eastern North American colonial settlements, or perhaps that the burials were destroyed sometime in the past either by natural or cultural processes (see Figure 4).

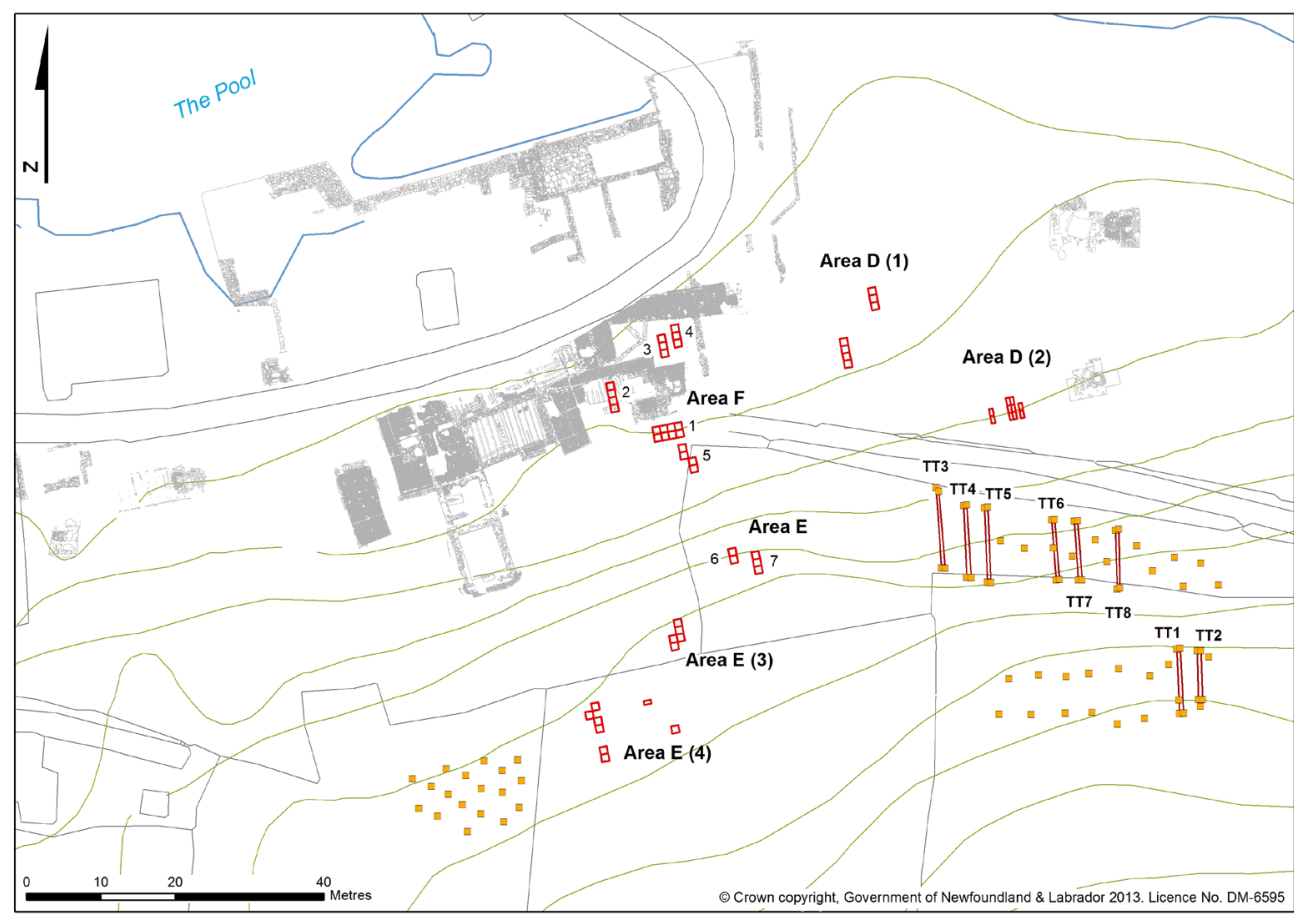

Figure 4: Map of Lacy's excavation areas, 2016/17. Areas tested were of high probability for burials but were negative. This expands our understanding of the Newfoundland colonial burial landscape (printed with permission (Lacy 2017)).

Excavations at Cupids are ongoing, led by archaeologist William Gilbert (of the Baccalieu Trail Heritage Organization). The graves identified in 2008 were to the east of the historic settlement, and if these can be dated accurately to the seventeenth century then the area would be the oldest organized British burial ground in what is now Canada. The eastern location of the burials is slightly elevated from the rest of the settlement, on the gentle north-west-facing slope where the settlement is located, which is a likely location for the burial ground according to the statistical analysis (Lacy 2017). 
The burials may or may not be within the fortified settlement, as the location or existence of a south-east wall is unknown. While the identified eighteenth-century burial ground at Cupids is a likely location for earlier, seventeenth-century burials as well, evidence of seventeenth-century remains, or materials has not been located or dated at the burial ground at the time of this paper. The Cupids burial ground presents an interesting case of a visible burial landscape for the eighteenth century, but a lost burial landscape when considering the seventeenth century.

Both historic settlements are similarly accessible to the general public. They are located approximately one hour from St John's - the capital city of Newfoundland - and operate as protected provincial historic sites with museums, active archaeological investigations, and guided tours of the sites during the summer (Colony of Avalon Foundation 2018; Cupids Legacy Centre 2018). At Cupids and Ferryland, visitors can engage with the historic site and landscape through stories of the people who lived there, based on the interpretation of the archaeological record in conjunction with historic documents. Tours at both sites during the field season (approximately June to September) have the potential to encourage active discussion about death in the past, creating an environment to explore themes relating to death and dying, both in the past and the present.

\section{Encouraging engagement with burial landscapes and mortality}

Public engagement with mortuary archaeology is often the topic of ethical debates, especially in a museum context (Lohman 2013: 122-38; Pearce 1990: 59, 76). However, when exploring a physical space with no visible human remains, engagement is far more theoretical and dependent on the interactions with the site itself, as well as the tour guides, archaeologists, and anyone else responsible for the presentation of the site. Undiscovered, lost burial landscapes provide a blank canvas for discussions on death and mortality in modernity through a historic context, and the sites of Cupids and Ferryland are perfect candidates for such interactions. 
Public engagement with archaeological deposits that cannot be seen and experienced might seem like a difficult concept to present to visitors, but such aspects of the landscape can be worked into the narratives which archaeologists and tour guides present to visitors. Staff at Cupids and Ferryland have a high rate of oneon-one interactions with visitors. Tour guides, usually students or local community members, could use that position to initiate conversations about death and dying at the early colonies, as part of the story of the sites. Currently, visitors to Cupids are shown the eighteenth-century burial site, and informed that the burials have not been dated to the seventeenth century, while at Ferryland, tour guides do not currently provide burial discussion in their tours but discussions on the deaths during the winter of 1628 could easily be implemented.

During tours at Cupids, the eighteenth-century burials are a starting point to exploring the burial landscape of the site. They are visible in the eastern portion of the settlement and have been incorporated into the tour as an aspect of the physically accessible modern landscape. While observing the excavated gravestones, visitors are informed that these burials were dated to the eighteenth century, and the seventeenth-century burials have not been found yet, despite having documentary evidence of many deaths at the seventeenth-century plantation. Visitors are presented with a laminated book detailing death in the 1600s, compiled from the plantation records. These records are the only surviving physical evidence indicating that the individuals were buried nearby. When presented with this information, visitors can reflect on burial practices from the seventeenth century through to the twentyfirst century. Burial grounds which were originally located close to settlements were replaced with burials on the outskirts, away from the direct, daily sight of most of the population. This process began as early as the turn of the nineteenth century and persisted into the twentieth century (Dwight 1823; Lacy 2017). As the seventeenthcentury burials at Cupids have not been identified yet, there is an opportunity to guide visitors to view the entire landscape before them as a potential burial landscape and speculate where the best spot for burials might have been. 
Potential discussion on this topic could begin by asking visitors why they think the eighteenth-century people were buried in this particular location, and what makes this spot different than a location closer to, or farther away from the plantation. Visitors might then discuss other locations near the settlement that might be good candidates for graves, and why. Tour guides could then direct the discussion by asking visitors question such as 'Why do you think they buried their dead so close to the town, instead of around the harbour, or up the hill? How does this compare to what we do now, in the twentieth and twenty-first centuries?'

By connecting the discussion of historic burial practices with modern ones, visitors will gain a better understanding of the choices people made when dealing with death in the seventeenth century.

Tours at Ferryland rely heavily on the ongoing archaeological work to guide visitors through the settlement. During 2016 and 2017, visitors on tours were brought to the locations I was excavating throughout the settlement to discuss the ongoing search for the seventeenth-century burial ground at the site. I used that opportunity to ask if the visitors had been told of the only recorded deaths from the early 1600s, located not far from where we were standing. The Mansion House, built for George Calvert and his family was used as a residence, a space for Anglican and Catholic prayer, and a hospital during the difficult winter in 1628/29 (Figure 5). As the surviving record of deaths in early Ferryland were associated with the Mansion House, which also acted as a church, and the gravestones were recovered nearby, it was suggested to me during fieldwork that perhaps the burials were near the structure. Several individuals died inside the house, but the sources identify who they were, what they died of, and where they were buried was never created or has not survived, so any unexcavated area around the settlement has the potential to contain a burial ground. However, excavations near the Mansion house have not revealed indications of burials; this is most likely due to the compact nature of the settlement not providing much open space within the fortifications.

When discussing my excavation with visitors, I was frequently asked questions about the location of graves, and burial practices, which would often become talks about historic versus modern burial practices. Here are some examples of the type of discussions I had 
with visitors at Ferryland, after explaining my research objectives to them.

Q: 'If you're looking for graves, why are you looking so close to the houses?'

A: 'In the seventeenth century, people would be buried close to homes in the middle of town. They liked to keep their loved ones nearby.'

Q: 'Was it common to bury people in the middle of towns?'

A: 'Yes! Based on my research, even the burial grounds that weren't right in the middle of town were still very close to the living areas'

Q: 'Why don't we do that anymore?'

A: 'Well there isn't a lot of room in cities anymore! It wasn't until the eighteenth century, when the burial grounds became crowded, that people started to open burial spaces outside of their settlements. In the nineteenth century, the reasons for this were more based on health and morality than practicality, but it happened all the time, and people began to prefer the garden cemeteries outside of town to the 'old' burial grounds.' Q: 'What if they were buried at sea, instead of in the ground?' A: 'We do have gravestone fragments which suggests that there was a burial ground here, but it wasn't common to bury people at sea unless they were sailors who died on a ship.

Q: 'But if they died in the winter, how could they have dug graves?'

A: 'They probably didn't. Since Western societies didn't embalm until the nineteenth century, the bodies were probably kept in an unheated building until the spring, when the graves could be dug.'

Q: 'Was there a church they could have been buried beside?'

A: 'As far as we know, there was no church constructed at Ferryland during Calvert's time here. The Mansion House, Calvert's home, was used to hold Anglican and Catholic services, but excavations around the house have shown no indication of graves.' 


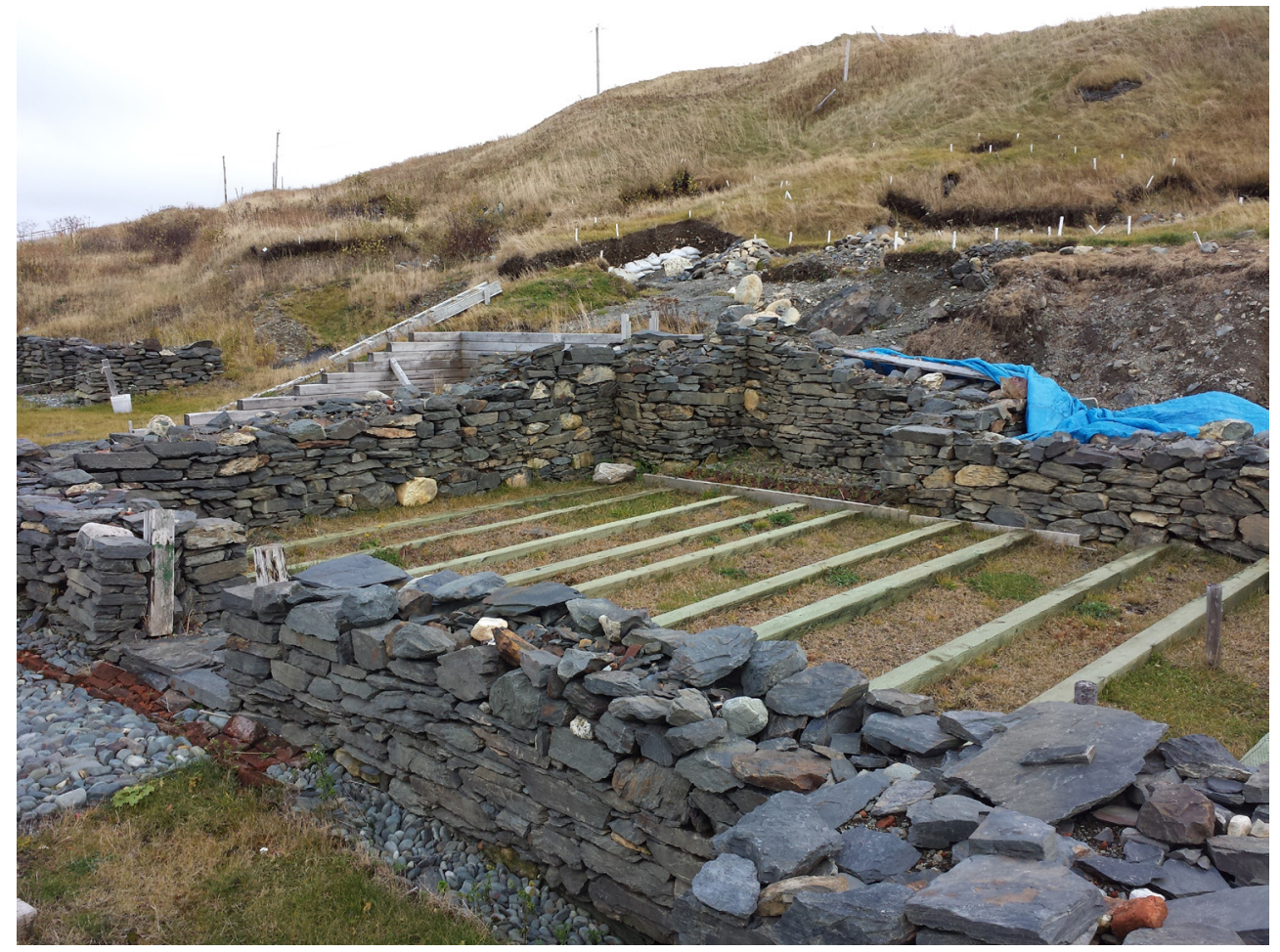

Figure 5: The Mansion House, where the only recorded deaths of the 1620 s occurred (photo by author, 2015).

Visitors appeared to appreciate the comparison of historic burial practices and modern ones, as it allowed them to use their own knowledge to connect with the past. One visitor, who had previously worked as a grave-digger, explained how they would dig graves by hand, a practice which had not changed for hundreds of years before the use of machinery.

Speaking frankly to visitors about the use of space near settlements as a burial ground, even if its location is still currently unknown today, opens the door for an important conversation on death and dying to the public. Through the lens of historic death, archaeologists can discuss modern fears and uncertainties about dying as it was seen by different cultures and societies. By encouraging visitors to contemplate the spaces before them as a potential burial landscape, they are engaging with an aspect of 
that landscape. Asking questions such as why, where, how, and when might people have been buried in specific areas allows archaeologists and visitors to gain a new awareness of the space that they are all occupying in that moment. Discussing death and burial with visitors at public archaeology projects such as Cupids and Ferryland is something which should be encouraged freely, and archaeologists should continue to use their position as so called 'death dealers' (Meyers and Williams 2014: 155) to promote open discussions about mortality. Along with direct engagement and discussion with visitors, archaeologists can employ social media platforms to expand the accessibility of their research, which helps to create open access of archaeological data. Through platforms such as Twitter, personal blogs, Instagram, or Facebook groups, discussions of historic death and burial are not limited to the several weeks that an excavation might have.

\section{Conclusions}

There is a growing interest in mortuary archaeology to improve public outreach, access, and engagement with fieldwork and collections where it is appropriate to do so (Williams and Williams 2007; Williams and Atkin 2015). While there are ongoing ethical debates about the excavation and display of human remains in many parts of the world (Curtis 2003; Lohman 2013; Pearce 1990; Renshaw 2007), this article suggests that by promoting engagement through verbal dialogue with the local communities and visitors during fieldwork, the burial landscape of a historic period site can be better understood.

Archaeologists are uniquely situated between two groups; death professionals who deal regularly with the modern dead and the public who encounter death in a subtler way. As directly argued by Giles and Williams (2016) we deal indirectly with themes of mortality every day as researchers and field technicians, and as a result, we have an excellent platform with which to open a discussion about death and dying with visitors through the medium of death and dying throughout history. Exploring human mortality through archaeology can be seen as a gentle way to ease into discussions of modern death, allowing visitors to ask questions that 
they might otherwise feel uncomfortable asking, facilitated by the open and engaging discussion already taking place.

This article advocates the use of unidentified or lost burial grounds as a catalyst for discussions of death and dying at public archaeological excavations, heritage tours, and historic sites. For instance, a heritage walking tour in the city of Baltimore, Maryland, could easily mention the theories over the placement of the earliest burial ground south-east of the present settlement as a means to discuss early burial practices in colonial America. Visitors to Guilford, Connecticut could be greeted by an interpretation panel at the well-preserved seventeenth-century Guilford Green, which discussed the Green's original use as a Puritan burial ground, and the high likelihood that it was only the gravestones and not the burials themselves that were relocated by 1817 (Bloomer 1994: 60; Dee 1998; Sexton 2002, 4; Smith 1877: 37-38). A significant aspect of a site's history, burial have the power to provoke thought and discussion from researchers and the public, and to employ such 'lost' burial landscapes as part of a site's engagement provides a space to ask questions and consider the landscape before them.

To open dialogues on mortality at a colonial site, archaeologists and tour guides can explore comparisons to modern burial practices, and why these practices have changed through time. While visitor engagement with a lost burial landscape may appear as an abstract concept, through open discussion facilitated by archaeologists and tour guides, visitors can gain a better understanding of how settlements and burial grounds were established in the colonial period. By promoting open discussions about death, a more holistic narrative of history can be achieved, and visitors will come away with a better understanding not only of how Europeans settlers in North America lived and died centuries ago, but how our relationship with the dead has drastically changed in the twentieth- and twentyfirst centuries. 


\section{References}

Anschuetz, K. F. and Scheick, C. L. 1998. Unveiling Archaeological Tierra Incognita: Evaluating Time, Place-Making and Tradition through a Cultural Landscape Paradigm. Paper presented at the 63rd Annual Meeting of the Society for American Archaeology, Seattle.

Ancestry. 2018. Ancestry. https://www.ancestry.ca/

Bartram, A. 1978. Tombstone Lettering in the British Isles. London, Lund Humphries.

Baugher, S. and Veit, R. F. 2014. The Archaeology of American Cemeteries and Gravemarkers. Gainesville, University Press of Florida.

Blachowicz, J. 2006. From Slate to Marble: Gravestone Carving Traditions in Eastern Massachusetts, 1770-1870. Evanston, Illinois, Graver Press.

Bloomer, N. 1994. Guilford, Connecticut - The Guilford Green. Places Journal 9, 56-65. Retrieved on 2 June 2018 from WWW http://escholarship.org/uc/item/8fc3x8mk

Cannon, A. 2002. Spatial narratives of death, memory and transcendence. In H. Silverman and D. B. Small (eds), The Space and Place of Death. Archaeological Papers pf the American Anthropological Association 11. American Anthropological Association, Arlington, Virginia, 191-199.

Carter, M., Gaulton B. and Tuck, J. A. 1998. Archaeology at Ferryland, Newfoundland, 1997. Avalon Chronicles 3, 49-62.

Cell, G. T. 1969. English Enterprise in Newfoundland 1577-1660. Toronto, University of Toronto Press.

Cell, G. T. (ed.) 1982. Newfoundland Discovered: English Attempts at Colonisation 1610-1630. London, The Hakluyt Society.

Colony of Avalon Foundation. 2018. Colony of Avalon. Retrieved on 2 June 2018 from WWW http://colonyofavalon.ca/ 
74 - Robyn LACY - Public Engagement through Burial Landscapes

Cupids400. ND. Cupids Cove Plantation Site: World Class Archaeology at Work. Accessed on 16 August 2017. Retrieved on 2 June 2018 from WWW http://www.cupids400.com/english/ dig/plantation.php

Cupids Legacy Centre. 2018. Cupids Legacy Centre. Retrieved on 2 June 2018 from WWW http://www.cupidslegacycentre.ca/index. php

Curtis, N. G. W. 2003. Human remains: The sacred, museums and archaeology. Public Archaeology 3 (1), 21-33.

Dee, J. 1998. Bones beneath your feet: Unmarked graves might be closer than you think. Hartford Courant, Collections. 31 October 1998. Retrieved on 2 June 2018 from http://articles.courant. com/1998-10-31/news/9810310176_1_prison-inmates-townbones-beneath-your-feet

Dwight, T. 1823. Travels in New England and New York, Volume II. Cambridge MA, The Belknap Press of Harvard University.

Gaulton, B. C. 2006. The Archaeology of Gentry Life in seventeenthcentury Ferryland. Unpublished PhD thesis, Department of Archaeology, Memorial University of Newfoundland.

Gaulton, B. C. and Miller, A.F. 2009. Edward Wynn's 'The Brittish India or A Compendious Discourse tending to Advancement (circa 1630-1631)'. Newfoundland and Labrador Studies Journal 24(1), 111-120.

Gilbert, W. 2003. Finding Cupers Cove. In J. A. Tuck and B. Gaulton (eds) Avalon Chronicles: The English in America 1497-1696. Vol 8. Newfoundland, The Colony of Avalon Foundation, 117-54.

Gilbert, W. 2008. New discovery: cemetery discovered at Cupids Site. Baccalieu Trail Archaeology. Retrieved on 2 June 2018 from WWW http://www.baccalieudigs.ca/default. php?display $=$ modDiscoveries $\&$ pageNum $=5$

Gilbert, W. 2013. Excavations at Cupids (CjAh-13), 2012. In S. Mills (ed.) Provincial Archaeology Office 2012 Archaeology Review, February 2013, Volume 11. 80-84. Newfoundland and 
Labrador: Department of Tourism, Culture, and Recreation. Retrieved on 2 June 2018 from WWW http://www.tcii.gov.nl.ca/ pao/newsletters/pdf/Vol11-2012.pdf

Giles, M. and Williams H. 2016. Introduction: mortuary archaeology in contemporary society. In H. Williams and M. Giles (eds), Archaeologists and the Dead: Mortuary Archaeology in Contemporary Society. Oxford, Oxford University Press, 1-20.

Greenspond Historical Society. 2018. Greenspond Historical Society, Bonavista Bay, Newfoundland. https://www.facebook. com/groups/6798324646/

Guy, J. 1611. A Letter from John Guy at Cupers Cove to John Slany and the Council of the Newfoundland Company, May 16, 1611. Retrieved on 2 June 2018 from WWW http://www. baccalieudigs. $\mathrm{ca} /$ default. php?display $=$ cid30

Jackson, J. B. 1984. Discovering the Vernacular Landscape, New Haven, Yale University Press.

Lacy, R. S. 2017. Here lieth interr'd: An Examination of 17th-century British Burial Landscapes in Eastern North America. Unpublished Master's Thesis, Department of Archaeology, Memorial University of Newfoundland. St. John's, Newfoundland.

Lacy R. S., Gaulton, B.C. and Piercey, S.J. 2018. Inscriptions, outcrops and XRF: analysis of the Ferryland gravestones. North Atlantic Archaeology 5, 91-110.

Lohman, J. 2013. Museum at the Crossroads? Essays on Cultural Institutions in a Time of Change. Victoria, Royal British Columbia Museum.

McGee, R. 2008. Aboriginalism and the problems of Indigenous archaeology. American Antiquity 73(4), 579-97.

Meyers, K and Williams, H. 2014. Blog bodies: mortuary archaeology and blogging. In D. Rocks-Macqueen and C. Webster (eds), Blogging Archaeology. E-book: Succinct Research, 152-178.

Miller, A. F. 2013. Avalon and Maryland: A comparative historical archaeology of the seventeenth-century New World provinces 
76 - Robyn LACY - Public Engagement through Burial Landscapes

of the Lorde Baltimore (1621-1644). Unpublished PhD Thesis. Department of Archaeology, Memorial University of Newfoundland.

Morton, N. 1669. New England's Memorial. Boston. Sixth edition: 1855. Congregational Board of Publication.

Mytum, H. 2004. Mortuary Monuments and Burial Grounds of the Historic Period. Manuals in Archaeological Method, Theory and Technique. New York, Springer.

Phillips, C. and Allen, H. (eds) 2011. Bridging the Divide: Indigenous Communities and Archaeology into the $21^{\text {st }}$ Century. $1^{\text {st }}$ Edition. Walnut Creek, CA, Left Coast Press.

Pearce, S. M. 1990. Archaeological Curatorship. Leicester, Leicester University Press.

Renshaw, L. 2007. The iconography of exhumation: representations of mass graves from the Spanish Civil War. In T. Clack and M. Brittain (eds), Archaeology in the Media. Walnut Creek, California, Left Coast Press, 237-52

Rugg, J. 2013. Choice and constraint in the burial landscape: reevaluating twentieth-century commemoration in the English churchyard. Mortality 18(3), 215-34.

Sayer, D. 2010. Who's afraid of the dead? Archaeology, modernity and the death taboo. World Archaeology 42(3), 481-91.

Sewall, S. 1878. Diary of Samuel Sewall, 1674-1729. Collections of the Massachusetts Historical Society. Boston, Massachusetts Historical Society.

Sexton, J. 2002. The Guilford Green: an ever-changing landscape. Connecticut Trust for Historic Preservation. Retrieved on 2 June 2018 from http://www.towngreens.com/DOCUMENTS/tg_ guilford_case.pdf

Slater, J. A. 1987. The Colonial Burial Grounds of Eastern Connecticut and the Men Who Made Them. Memoirs of the Connecticut Academy of Arts \& Sciences. Hamden, Connecticut, Archon Books. 
Smith, R. D. 1877. The History of Guilford, Connecticut. Albany, NY: J. Munsell, Printer. Retrieved on 2 June 2018 from https:// catalog.hathitrust.org/Record/009596525

Stannard, D. E. 1977. The Puritan Way of Death: A Study in Religion, Culture, and Social Change. Oxford, Oxford University Press.

Tuck, J. and Gaulton, B. 2003. The archaeology of Ferryland, Newfoundland, until 1696. In J. A. Tuck and B. Gaulton (eds), Avalon Chronicles: The English in America 1497-1696, Vol. 8. Newfoundland, Colony of Avalon Foundation, 187-224.

Williams, H. and Atkin, A. 2015. Virtually dead: digital public mortuary archaeology. Internet Archaeology 40. Retrieved on 27 June 2018 from http://intarch.ac.uk/journal/issue40/7/4/index. html

Williams H. and Williams E. J. L. 2007. Digging for the dead: archaeological practice and mortuary commemoration. Public Archaeology 6 (1), 47-63. 
